\title{
The Improvement of Accreditation through Evaluation on Management Standards in Madrasah Tsanawiyah
}

\author{
Sukmawati ${ }^{1}$, Yusak Ujang ${ }^{2}$, Soeharto ${ }^{3}$ \\ ${ }^{1}$ Science Education, Tanjungpura University, Indonesia \\ E-mail: sukmawati@fkip.untan.ac.id \\ ${ }^{2}$ Science Education, Tanjungpura University, Indonesia \\ E-mail: yusacujang@ rocketmail.com \\ ${ }^{3}$ Educational Sciences, University of Szeged, Hungary \\ E-mail:Soeharto.soeharto@edu.u-szeged.hu
}

(Received: November-2018; Reviewed: March-2019; Accepted: March-2019; Published: April-2019)

\begin{abstract}
This research was a descriptive study and conducted at MTs Al-Anwar. The research process is carried out in several stages, namely: the preliminary stage, pre-field, fieldwork, research, analysis of data collected findings, data presentation, and research reports. Data collection techniques are interviews and observation with a tool to collect data on observation and documentation format. The results are obtained 1) The gap between expectations and reality on management standards; 2) Obstacles encountered in Madrasah Tsanawiyah Al-Anwar in implementing management standards, namely (a) The budget is not enough to carry out activities (RKAS) because the costs incurred are not in accordance with the plan; (b) There is no community assistance other than committee funds; (c) The number of education levels in one location has resulted in the development of madrasah tsanawiyah being hampered; (d) Adjacent to the Madrasah Tsanawiyah there are several schools around the place; 3) Efforts made by Madrasah to overcome obstacles through 1) Carry out activities in accordance with available funds; 2) The principle of openness to financial conditions to committees and teachers and staff; 3) There is BOS assistance and participating in the DNDMFN BOS, so that it can complement the needs of madrasah.
\end{abstract}

Keyword: Improvement; Accreditation; Evaluation; Management Standards.

\section{INTRODUCTION}

Various efforts to improve the quality of education have been carried out, but until now education in our country still faces many challenges in terms of quality. In an effort to realize and improve the quality of schools, good and directed management is needed. Good management should refer to the National Education Standards (SNP). To improve quality of education some research had been conducted. Reeves, Boet, Zierler, \& Kitto (2015) had done research to education and practice in schools, and Mincu (2015) also conducted a research about teacher quality and school improvement. The research found that the role of evaluation and management standards is extremely important to improve quality of education.

According to Government Regulation No. 19 of 2005 SNP Article 49 paragraph (1) states: management of education units at the level of primary and secondary education implements school-based management as indicated by independence, participation, openness, and accountability. Furthermore, Article 50 paragraph (1) states that each education unit is led by the principal in charge. Stated that to investigate the effect service 
quality on education the improvement of school quality and management has to be improve (Ali, Zhou, Hussain, Nair, P. K \& Ragavan, 2016).

Furthermore PP No.13 Year 2015 Article paragraph (1) concerning management standards as follows "Management Standards are criteria regarding planning, implementation, and supervision of educational activities at the level of district / city, provincial or national education units in order to achieve efficiency and effectiveness in the implementation of education.

Referring to the government regulations above, it can be concluded that for good school management the principal and staff can implement standard management criteria which include (a) planning school activities (b) carrying out school activities in accordance with the planning and overseeing ongoing activities in the school. Laurie, Nonoyama-Tarumi, Mckeown, \& Hopkins (2016) stated that contribution of good school management will lead good quality of education, so government should give standards to manage school regulation.

According to interview and observation of schools target, Madrasah Tsnawaiyah Al-Anwar Pontianak is one of the private madrasah having its address at Jalan Khatulistiwa Gg. Pawarsal, Central Siantan Village, North Pontianak District, West Kalimantan. This Madrasah was established in 1992 (26 years), has a total of 14 teachers and 164 students and has a land area of 4,721 m2. This Madrasah has been accredited "B" in 2017. Because the madrasah has been established for a long time, it should be possible for this madrasah to achieve accreditation "A." For this reason, researchers are interested in evaluating what preparations have been made by madrasah especially for "Management Standards," so that with careful preparation it is expected that in the future they can achieve the expected accreditation, "A." Interview and observation are chosen because for descriptive research, it will be impactful and needed (Jensen, Sonnemann, Roberts-Hull, \& Hunter, 2016).

Based on the observations of researchers in several schools / madrasah, this accreditation preparation was carried out by the school ahead of the visitation carried out by the assessor, so the results were not maximal. The implementation of education national standard is essential to improve school quality and have to included in standards in accreditation (Maba,
2017). Cooke, B., \& Alcadipani (2015) state that school management and evaluation were important to prepare standards of accreditation to maintain school quality. Some research also found that accreditation was carried out by the school without good evaluation and management shown minimum result for improving quality of school and education (Agih, 2015). according to this finding, researchers found among others (1) Documents needed seemed new made; (2) Schools/Madrasah are newly painted; (3) New educators and education personnel are recruited to comply with the standards; (4) Three months of visitation, the principal and education staff work all day, and some even go to bed at school; (5) Visitation activities at accreditation are very frightening; (6) The RKAS program seems newly planned; (7) The new school page is tidied up; and (8) In some rooms it seems to have been tidied up.

Referring to the above phenomena, researchers feel interested in evaluating the preparation and implementation of management standards at the Madrasah Tsanawiyah AlAnwar, North Pontianak. This evaluation is important because the madrasah is a private madrasah that has so many rivals with other private schools in Pontianak. With good preparation, it is expected that Al-Anwar MTS can increase the accreditation predicate from "B" to "A," or at least remain ranked B and do not get a status that is not accredited. If this happens, it can be predicted that the MTS will be closed.

Therefore, the researcher will evaluate using "DISCREPANCY MODEL." Where this model emphasizes the view that there are gaps between expectations and reality of each component that will be evaluated on management standards that refer to the 2017 accreditation instrument. the 2017 accreditation instrument was chosen because schools have to fulfill all standards in acreditation to improve school management and quality

The purposes on this research are to Describe the gap between expectations and reality on management standards at MTS AlAnwar, to Describe the obstacles encountered in implementing management standards at MTS Al-Anwar, and to Describe the efforts made by MTS Al-Anwar in overcoming these obstacles. 


\section{METHOD}

This research uses a descriptive method. Descriptive method is used in this research because it will be easy to analyse and depict school management and evaluation (Perrotta, \& Williamson, 2018); Leach, Hofmeyer, \& Bobridge, 2016). The research process is carried out in several stages, namely: the preliminary stage, pre-field, fieldwork, research, analysis of data collected findings, data presentation, and research reports. In this study data collection techniques used are direct communication techniques with data collection tools are interviews and direct observation techniques with a tool to collect data on the format of observation and documentation. Data on interviews and observations are used to obtain primary data, while documentation is used to obtain secondary data.

\section{RESULT AND DISCUSSION}

\section{Result}

The data obtained from this study are data in the form of sentence narratives. Data collection is carried out on an ongoing basis including conducting interviews, observation, and documentation. In the implementation of interviews and documentation of observation data can also be carried out jointly and interviews and observations can also be carried out simultaneously.

Based on the research that has been done, researcher find some result. Vision, mission, and goals have met two provisions, namely formulated based on input from the madrasa community and decided at a school meeting. RKJM and RKT have met three provisions, namely compiled according to recommendations for self-evaluation, decided at the meeting, and put in written documents. Management guidelines at school using some document such as KTSP, educational calendar, Organizational structure, division of teacher assignments, academic regulations, school rules, teacher's code of ethics, and chool Operational Costs (BOS). Madrasah organizational structure is determined by meeting and headmaster. Madrasah can only carry out RKT of approximately $65 \%$ of planned activities. Student activities at Madrasah include some activity like acceptance of new students, scout activities, fostering achievements, and alumni Search. Madrasah already implementing management of curriculum fields. Entrusting education staff and education personnel includes some activity such as meeting the needs of the number of educators \& education staff, empowering educators \& education personnel, development of educators \& education staff, awarding educator \& education staff awards. Carrying out teachers performance assessments namely according to duties and expertise, workload balance, active in carrying out tasks (observation), become an outstanding teacher at the sub-district level, take part in table tennis competitions. Madrasah in managing to finance have referred to the some specified needs. Madrasah have collaborated with 5 institutions In field of education, health, police, religion and society, and development of interests and talents. The headmaster of madrasah carried out self-evaluation once in 2 years. The head master of Madrasah have carried out 9 leadership tasks. Madrasah have applied 6 principles of leadership. Madrasah already have school operators assigned to manage SIM

\section{Discussion}

Based on the results of the research findings, then in this section, a discussion will be presented by comparing the findings with the evaluation criteria so as to produce a conclusion. By conducting this discussion, it is hoped that it can capture the meaning and provide useful benefits for all parties with interest in the results of this research. In connection with this matter, the discussion on "Improving Accreditation through Evaluation on Management Standards in the Tsanawiyah Al-Anwar Madrasah in Pontianak will be found in accordance with the items contained in the management standard.

To determine the value of each research item refer to the scoring technique found by Rinses Likert in (Wirawan, 2001).

1. Vision, Mission, and Objectives

In the results of the research that has been stated previously, that the school evaluated the first item of the standard S / M management obtained the $\mathrm{C}$ value with the category (moderate), meaning that from the 4 conditions required, 2 provisions have been fulfilled. This shows the level of achievement of the vision, mission, and objectives of 50\%. Activities that have not yet been carried out by the S / M are: 1) Socializing to all school members and stakeholders, 2) Periodically re-lending the vision, mission, and objectives. 
School's vision, mission, and goals are three words that are interrelated and have different meanings. School vision is a moral imagination that describes the desired school profile in the future. While the mission is the elaboration of vision in the form of the formulation of duties, obligations, and action plans that are used as direction to fulfill the demands set forth in the vision. Then the aim of the school is to describe the level of quality that needs to be achieved in the medium to four-year term (Syaifuddin, 2007).

\section{RKJM and RKT}

The evaluation results in point 2 of the management standard get a B value (good) because of the 4 conditions required, 3 conditions are met, meaning that the level of achievement on this item is $75 \%$. Activities that have not been carried out by the S / M are ratifying the Medium Term Work Plan (RKJM) and the Annual Work Plan (RKT) by the education office / ministry of ministry. Every school must have a plan to improve the quality of the school. There are several types of programs / plans prepared by schools, namely: short-term programs (1 year), mid-term programs (4 years), and long-term programs (8 years). Anwar, Qomari \& Sagala (2004) asserts that planning is the process of implementing and utilizing resources in an integrated manner which is expected to support activities and efforts carried out effectively and efficiently in achieving school goals. Therefore S / M should be able to make RKJM / RKT by referring to the 5 resources in the school (man, money, machine, method, material). In connection with this description (Manulang, 2009) says a good plan must contain the following characteristics: (a) Use of simple words that are easy to understand; (b) Flexible; (c) Has stability; (d) Under consideration; (e) Includes all necessary actions 3. Management Guidelines

The evaluation results in point 3 of the management standard regarding the guidelines for managing S / M obtain an A with a category (very good) because of the 9 provisions that must be met S / M already has 8 guidelines which include: KTSP, academic calendar, teacher assignment, regulations academic, discipline, code of ethics, and operational costs. The level of achievement of this item is $88 \%$.

With the resources that the school has as mentioned above, it is expected that $\mathrm{S} / \mathrm{M}$ can manage the school effectively and efficiently. The principal is a driving force, determining the direction of school policies that will determine how school goals and education are generally realized. Pidarta in (Mulyasa, 2004) suggests three types of skills that principals must possess are: conceptual skills namely skills to understand and operate organizations, human skills namely skills to cooperate, motivate and lead, and technical skills namely skills in using knowledge, techniques , methods, and equipment for completing certain tasks.

\section{Organizational Structure}

The evaluation results in point 4 of the management standards regarding organizational structure obtain $\mathrm{C}$ values with categories (moderate), achievement levels of $50 \%$. This means that there are 2 out of 4 provisions that are not reached, which include: the organizational structure of the school is not socialized with the school community; not authorized by an authorized official.

In an organization, there is a group of people to work together in order to achieve a predetermined goal. For this reason, the headmaster should be able to divide up the work to each person in the school (teachers and staff), their respective students. This division can be described in the school organizational structure. The school organizational structure is formed through school meetings, so the principal establishes and approves by making a decree. Furthermore, the school principal socializes to all school members and stakeholders by recording the minutes of the meeting book, attendee list, and minutes. In making the organizational structure should be able to use the type of bureaucratic organizational structure. The advantages of this type are technical efficiency, reducing popularity, predictable achievement, job security, competent technically, minimizing the need for direction and avoiding actions to obey (Gitosudarmo, 2000).

With the existence of an organizational structure and details of the duties of each personnel, it is expected that the process of implementing education can be carried out properly. Even though there are obstacles to the implementation, the obstacles can be solved immediately.

5. Implementation of Annual Activities

Based on the evaluation in point 5 of the annual activity (RKT) the school / madrasah gets D score with a category (bad), the level of achievement is $65 \%$. This means that many of the annual activity plans cannot be implemented. 
Based on the results of interviews with school principals and teachers, this RKT cannot be carried out optimally due to lack of funds. The source of funds obtained is only 2, namely BOS funds and funds from parents who are known by the school committee. Funds from parents (committee) were only Rp. 15,000 per month. The number of study groups is 6 with 164 students.

RKT is an annual work plan prepared jointly by madrasah / school with the madrasah committee. The needs of the madrasah and the aspirations of the community are the main basis for the preparation of the RKT aimed at expressing what is needed by the $\mathrm{S} / \mathrm{M}$ and the expectations of the community around the madrasah. (Muhaimin, 2009) stated that the RKT of madrasah was useful to make; work guidelines in the development of madrasah, a means to conduct monitoring and evaluation as well as material to identify \& propose necessary educational resources.

With the existence of a clear RKT, all interested parties such as parents, teachers, employees, and committees will know what is needed by the madrasah, what needs to be done to improve the condition of the madrasah, the purpose, and objectives of the activities that will be carried out by the madrasah. It can be concluded that the RKT can be used as a guideline and monev (monitoring and evaluation) tool for implementing school activities.

\section{Student Activities}

Based on the evaluation in point 6 about student madrasah getting a $\mathrm{B}$ with a category (good), the level of achievement is $80 \%$. This means that almost all provisions in student activities are fulfilled, only one is not yet namely counseling services.

Student activities are structuring and regulating student activities starting from entering school to graduating students. Student activities are not only in the form of recording data on students but include a broader one which can operationally help the efforts of the growth and development of students through the learning process in school.

Sutisna in (Mulyasa, 2004) states the task of the principal in student activities, namely: monitoring student attendance and problems related to it; acceptance of orientation, classification, and appointment of students to class; evaluation and reporting of learning progress; have a supervision program for students who have problems; student discipline control; implement health and safety programs; implement self-adaptation, social and emotional programs for students.

Therefore student activities are very important to be carried out as well as possible by the school in order to achieve school goals further the goals of national educators.

7. Management of the Curriculum Field

Based on the evaluation results in point 7 regarding the management of the curriculum, the madrasah gets an A (very good), an achievement level of $100 \%$.

Management of curriculum fields consists of: the implementation of KTSP; implementation of the education calendar; implementation of the teaching program; implementation of the assessment; and implementation of academic regulations. All documents needed on this item already exist and have been implemented. In connection with this, the results of Rutter's research from England 1979 in (Supardi, 2013) reported that effective schools have characteristics; emphasize learning (curriculum); plan together and work together in the implementation of directed learning and supervision from senior teachers and principals.

To implement the five aspects in point 7 , the principal and teacher should make lesson plans for each subject can carry out the teaching and learning process in accordance with the lesson plan and be able to carry out the evaluation of learning.

8. Utilizing Educators and Education Personnel

Based on the evaluation in item 8 about the utilization of educators, the madrasah gets an A (very good), the achievement rate is $100 \%$. This means that the five conditions required have been fulfilled.

Empowerment means giving strength. Freedom, knowledge, and skills to the teacher / staff. To make decisions and carry out work effectively. Madrasah has divided the work with the teacher according to their educational background. For the burden of teaching given according to the teaching hours that passed on each subject. While staff (TU) only 1 person all workloads are done by themselves. The division of teaching burden to the teacher / staff is a manifestation of democratic leadership. This is made clear by Agung (2012) that delegation of authority can be reflected in the work team, quality cycle, expansion of work, and staff / employee participation groups are also authorized to make decisions, training, and 
information so that employees can do work without close supervision.

9. Performance Evaluation of Educators and Education Personnel

Based on the evaluation in point 9 regarding the evaluation of educators performance, A (very good) is obtained. This means that all aspects in point 9 have met the requirements determined with a level of achievement of $100 \%$.

Physical performance assessment is carried out by madrasah through assignments given whether they can be implemented properly and responsibly; besides monitoring the attendance list; acquisition of charter, certificate; results of performance appraisal (SKP). The meaning of performance actually comes from the job performance word and also called actual performance or work performance achieved by an employee, in this case, the teacher and TU staff. Performance appraisal implies giving an assessment of the performance or how much it can contribute to the usefulness of a particular activity. Performance appraisal can also be used as a tool to determine whether the teacher / TU has provided adequate work results and has carried out performance activities in accordance with established standards. The purpose of performance appraisal is to improve or improve organizational performance by improving the performance of organizational HR (Mangkunegara, 2014).

10. Management of Financing

Based on the evaluation in point 10 regarding financing management, an $\mathrm{A}$ value (very good) is obtained. This means that all aspects in point 10 have fulfilled the requirements determined with a level of achievement of $100 \%$.

In managing to fund, the madrasah has considered the available resources, planned and implemented the use of the budget, made a report on the use of funds to the Al-Anwar committee and foundation. Regarding the financing management, Asriati (2018) emphasized that "In the use of the budget must meet the following criteria: there must be a report of costs; reports must be made uniformly, i.e., with the same functional standards; the report must show the overall operational costs of the institution."

Effective and efficient school financing is a shared responsibility of both the government and the community. Therefore it is necessary to build openness, participation, accountability in the misuse of education from planning to implementation and supervision.

\section{Community Participation}

Based on the evaluation in point 11 regarding community participation, $\mathrm{B}$ is obtained (good). This means that almost all aspects in point 11 are fulfilled according to the requirements determined by $83 \%$ achievement.

Society is the main component of the implementation of the education process. The contribution of the community in the school environment needs to be optimized as an empowerment effort in order to realize the vision and mission of the school with the new educational paradigm. In general, the role of society given in the form of participation given will be based on the level of culture owned by the community and the ability to understand at the level of the public policy process. Not all communities have been able to provide input, advice, and criticism at the level of policy formulation.

According to Ambar, Teguh, Sulistiyani (2007) so that the community has the ability to provide suggestions, ideas, criticisms, it is necessary to conduct a public education process, namely: providing a wide space for the community to convey inspiration without being burdened with sanctions and threats; provide information transparently to the public regarding local and national development; community involvement in policy formulation. The involvement of the community in school activities includes counseling about the dangers of drugs by the police, cooperation with religious leaders, cooperation with the health department, cooperation with the business world, cooperation with the development of blessings and interests.

\section{School Self Evaluation}

Based on the evaluation in item 12 about school self-evaluation, the B value is obtained (good). This means that some aspects in point 12 have been fulfilled in accordance with the requirements with a level of achievement of $75 \%$.

Self-evaluation activities are activities carried out by schools / madrasah to find out a comprehensive picture of $\mathrm{S} / \mathrm{M}$ performance covering the implementation \& national standards of education. According to technical guidelines for filling in accreditation instruments for junior high / madrasah years. S / M material should carry out self-evaluation every year starting from the new school year up to the end 
of the school year (July of the year runs until June of the following year). Almost all S / M make evaluations themselves when school accreditation is carried out / S / M should be able to make school self-evaluations every year and be archived in the form of documents.

\section{Carry out the Leadership Task}

Based on the evaluation in item 13 about self-evaluation S / M, the A value (very good) is obtained. This means that all aspects in point 13 are fulfilled according to the requirements carried out with a level of achievement of $100 \%$.

By looking at documents and hearing interviews of teachers and TU staff, it shows that the head of the madrasah (kamad) has carried out leadership tasks which include: describing the vision and mission; formulate goals; create a SWOT analysis; make RKT and RKJM; involving teachers and committees; motivating teacher / TU work; support effective learning; improve the quality of educators; set an example.

So that this leadership task can always be maintained / improved should the head of S / M try to improve leadership quality continuously through: thinking effectively in making decisions; communicate the results of thinking; increase participation in problem-solving; explore and enhance creativity (Nawawi \& Martini, 2004)

\section{Principles of Leadership}

Based on the evaluation in item 14 about the leadership principle, an A (very good) is obtained. This means that all aspects of the item are fulfilled according to the requirements determined with a level of achievement of $100 \%$.

The principles that have been implemented by the S / $\mathrm{M}$ are building goals together; increase creation and innovation; develop educator motivation; carry out monitoring and evaluation; make data-based decisions. Education in school is carrying out tasks in the field of educational leadership. The task of educator leadership is directly related to how to influence the people in a school so that together voluntarily want to participate in achieving organizational goals effectively and efficiently. So that people who are led to cooperate in this matter are teachers / TU schools, it is better for the heads of schools to implement the principles put forward by (Maslow, 2013)UL, namely: the principle of openness; principle of responsibility; principle of participation; flexible principle; accountable principle. Thus SDDKNF is effective in implementing leadership carried out by the head of the $\mathrm{S} / \mathrm{M}$.

15. Management Information System (SIM)

Based on the evaluation in item 15 concerning SIM, an A value (very good) is obtained. This means that all aspects of the item have been carried out in accordance with the conditions required with $100 \%$ achievement rate.

This SIM activity in S / $\mathrm{M}$ is conducted to communicate with students, parents, committees, and education offices about the data / information needed. The school already has an operator to input data about school activities, design school work, and send needed information from both the education office and the religious department. SIM in school is very necessary to carry out school administration activities. Currently in S / M for accreditation activities using the SISPENA system (Accreditation Assessment System). Before the assessor holds a visit to the school, the school has already filled out supporting data through SISPENA. This data must be in accordance with the documents available at the school. Vice versa, before the assessor visitation can see the school data through the SISPENA application. Thus the role of SIM is very helpful in facilitating administrative activities in schools.

\section{CONCLUSIONS AND SUGGESTIONS}

Based on the research that has been done, the results obtained can be summarized as follows: Implementation of management standards at the Madrasah Tsanawiyah AlAnwar Pontianak has been very well implemented. Obstacles encountered in Madrasah Tsanawiyah Al-Anwar in implementing management standards are the budget is not enough to carry out activities (RKAS) because the costs incurred are not in accordance with the plan. There is no community assistance other than committee funds@ Rp. 15,000 / students and BOS funds. Madrasah Tsanawiyah Al-Anwar under the umbrella of the Al-Anwar foundation. This foundation has a land area of $4,721 \mathrm{~m} 2$. In it, there are levels of PAUD education, Ibtidaiyah Madrasah, Madrasah Tsanawiyah, and Madrasah Aliyah. With the many levels of education in one location, the development of the madrasah tsanawiyah has been hampered. Adjacent to the Madrasah Tsanawiyah there are 
several schools around the place, this is a problem in itself. To recruit new students and use school committee money.

Efforts made by Madrasah to overcome obstacles through some path namely carrying out activities in accordance with available funds, the principle of financial openness to the committee and the teacher and staff. Contribution from BOS funds and participating in the DNDMFN BOS, so that it can complement the needs of madrasah, such as teachers who have been paid by the government are not paid anymore from madrasah.

According to the research finding, researchers offer some suggestion namely school should try to get a new land for the development of Islamic schools in a better direction, the headmaster can submit a proposal to the authorities to obtain funds to develop a standard madrasah schools and the head master can use committee money by being known by the foundation, and schools have to continue to improve the quality of learning with existing facilities and infrastructure.

\section{REFERENCE}

Agih, A. A. (2015). Effective school management and supervision: Imperative for quality Education service delivery. African Research Review, 9(3), 62-74.

Agung, I. (2012). Strategi Mengembangkan Organisasi Pembelajaran di Sekolah. Jakarta: Bee Media.

Ali, F., Zhou, Y., Hussain, K., Nair, P. K., \& Ragavan, N. A. (2016). Does higher education service quality effect student satisfaction, image and loyalty? A study of international students in Malaysian public universities.. Quality Assurance in Education, 24(1), 70-94.

Ambar, Teguh, Sulistiyani, R. (2007). Manajamen Sumber Daya Manusia. Yogyakarta: Graha Ilmu.

Anwar, Qomari \& Sagala, S. (2004). Profesi Jabatan Kependidikan dan Guru Sebagai Upaya Menjamin Kualitas Pembelajaran. Jakarta: Uhamka Press.

Asriati, N. (2018). Ekonomi dan Pembiayaan Pendidik. Bandung: LEKKAS.
Cooke, B., \& Alcadipani, R. (2015). Toward a global history of management education: The case of the Ford Foundation and the São Paulo School of Business Administration, Brazil. Academy of Management Learning \& Education, 14(4), 482-499.

Gitosudarmo, I. et al. (2000). Perilaku Organisasi. Yogyakarta: BPFE.

Jensen, B., Sonnemann, J., Roberts-Hull, K., \& Hunter, A. (2016). Beyond PD: Teacher Professional Learning in High-Performing Systems. Teacher Quality Systems in Top Performing Countries. National Center on Education and the Economy.

Laurie, R., Nonoyama-Tarumi, Y., Mckeown, R., \& Hopkins, C. (2016). Contributions of education for sustainable development (ESD) to quality education: A synthesis of research. Journal of Education for Sustainable Development, 10(2), 226-242.

Leach, M. J., Hofmeyer, A., \& Bobridge, A. (2016). The impact of research education on student nurse attitude, skill and uptake of evidence-based practice: a descriptive longitudinal survey. Journal of Clinical Nursing, 25(1-2), 194-203.

Maba, W. (2017). The implementation of education national standard in the instrument of school accreditation of Bali province education authority. International Research Journal of Engineering, IT \& Scientific Research, 3(4), 1-7.

Mangkunegara, A. P. (2014). Manajemen Sumber Daya Manusia. Bandung: PT. Remaja Rosdakarya.

Manulang. (2009). Dasar-Dasar Manajemen. Yogyakarta: Gajahmada University Press.

Maslow, A. H. (2013). A theory of human motivation. New York: Simon and Schuster.

Mincu, M. E. (2015). Teacher quality and school improvement: what is the role of research? Oxford Review of Education, 41(2), 253 269.

Muhaimin, et al. (2009). Manajemen Pendidikan. Jakarta: Kencana Prenada 
Media Grup.

Mulyasa. (2004). Manajemen Berbasis Sekolah. Bandung: Remaja Rosdakarya.

Nawawi, H. \& M. (2004). Kepemimpinan yang Efektif. Yogyakarta: Gajahmada University Press.

Perrotta, C., \& Williamson, B. (2018). The social life of Learning Analytics: cluster analysis and the 'performance'of algorithmic education. Learning, Media and Technology, 43(1), 3-16.
Reeves, S., Boet, S., Zierler, B., \& Kitto, S. (2015). Interprofessional education and practice guide no. 3: evaluating interprofessional education. Journal of Interprofessional Care, 29(4), 305-312.

Supardi. (2013). Sekolah Efektif Konsep Dasar dan Praktiknya. Jakarta: Raja Grafindo Persada.

Syaifuddin, M. (2007). Manajemen Berbasis Sekolah. Jakarta: Dirjen Perguruan Tinggi.

Wirawan. (2001). Evaluasi Teori, Model,Standar, Aplikasi, dan Profesi (R. Pers, ed.). Jakarta. 